\title{
Penerapan E-Learning dengan Platform Edmodo untuk Meningkatkan Hasil Belajar Mahasiswa
}

\author{
Maria Agatha Hertiavi \\ Program Studi Pendidikan Fisika, Universitas Pattimura \\ Email: agathahertiavi@gmail.com
}

\begin{abstract}
Abstrak
Pemanfaatan teknologi dalam proses pembelajaran mendorong terciptanya beragam media pembelajaran yang bisa dipilih untuk digunakan dalam pembelajaran. E-learning adalah pembelajaran berbasis pada jaringan internet yang dapat dilakukan dengan tidak dibatasi tempat dan waktu. Edmodo merupakan salah satu alternatif media penunjang e-learning. Tujuan penelitan ini adalah mengetahui kelayakan media serta perangkat pembelajaran e-learning berbasis edmodo, mengetahui respon mahasiswa terhadap penggunaan pembelajaran e-learning berbasis edmodo serta mengetahui hasil belajar mahasiswa pada mata kuliah Sejarah Fisika di Program Studi Pendidikan Fisika Universitas Pattimura. Teknik pengumpulan data dengan metode angket dan tes. Teknik analisis data menggunakan prosentase dan uji gain. Hasil analisis disimpulkan (1) Pembelajaran e-learning berbasis edmodo layak digunakan dalam pembelajaran. (2) Perangkat pembelajaran layak digunakan dalam pembelajaran e-learning berbasis edmodo. (3) Mahasiswa merespon baik penerapan pembelajaran e-learning berbasis edmodo. (4) Terjadi peningkatan kategori sedang setelah penerapan pembelajaran e-learning berbasis edmodo.
\end{abstract}

Kata Kunci: E-Learning, Edmodo, hasil belajar

\section{Implementation of E-Learning with Edmodo Platform to Improve Student's Learning Outcome}

\author{
Maria Agatha Hertiavi \\ Departement of Education of Physics, Universitas Pattimura \\ Email: agathahertiavi@gmail.com
}

\begin{abstract}
Technology in the learning process encourages the creation of a variety of learning media that can be selected for use in learning. E-learning is learning based on internet networks that can be done without limited by place and time. Edmodo is an alternative media to support e-learning. The purpose of this research are determine the feasibility of edmodo and e-learning devices, find out the students' responses of e-learning based on edmodo and find out the university student outcomes in the History of Physics, Physics Education Program at Pattimura University. Data collection using a questionnaire method and test. Data analysis using percentages and gain test. The results concluded (1) E-learning based on edmodo is appropriate for use in learning process. (2) E-learning based on edmodo devices are suitable for use in learning process. (3) University students responded the implementation of e-learning based on edmodo well. (4) There is an increase in the moderate category after implementation of e-learning based on edmodo.

Keywords: E-Learning, Edmodo, Learning Outcome
\end{abstract}




\section{PENDAHULUAN}

Menurut Hamalik (2011:10), sistem pengajaran adalah suatu kombinasi terorganisasi yang meliputi unsur-unsur manusiawi, material, fasilitas, perlengkapan, dan prosedur yang berinteraksi untuk mencapai suatu tujuan. Dalam Rusman (2014:1) Perencanaan pembelajaran terdapat tiga faktor yang harus diperhatikan, yakni kondisi pembelajaran, metode pembelajaran dan hasil pembelajaran. Pemanfaatan teknologi dalam proses pembelajaran mendorong terciptanya beragam media pembelajaran yang bisa dipilih untuk digunakan dalam pembelajaran. Penggunaan media elektronik seperti komputer, laptop, dan smartphone merupakan alternatif pemilihan media pembelajaran di abad ini. Sejalan dengan pendapat (Bezhovski, 2016) proses belajar mengajar e-learning diberikan menggunakan perangkat komputer atau perangkat seluler yang mampu mendukung pembelajaran. Media pembelajaran elektronik merupakan perangkat penting yang dapat digunakan oleh untuk meningkatkannya motivasi dan pendidikan siswa (Mateo, Rey, \& Hernández, 2010)

Di era revolusi industri 4.0, perkembangan teknologi informasi begitu pesat. Berbagai informasi dapat diakses dengan mudah dengan adanya jaringan internet. Kemajuan perkembangan teknologi informasi dan internet berdampak pada inovasi gaya belajar mengajar (Lin, Chen and Nien, 2014). E-learning mengubah sektor pendidikan dengan memungkinkan siswa untuk berbagi informasi dan data dengan cara yang relatif mudah (El-seoud et al., 2009).

Berdasarkan pendapat (Epignosis, 2014) E-learning adalah pembelajaran berbasis pada jaringan internet yang dapat dilakukan dengan tidak dibatasi tempat dan waktu. E-learning juga berarti penggunaan teknologi informasi untuk mendapatkan akses belajar mengajar (Arkoful, 2014). Elearning dibedakan menjadi dua (Algahtani, 2011) yaitu pembelajaran berbasis komputer dan pembelajaran berbasis jaringan internet. E-learning berbasis komputer adalah pembelajaran yang menggunakan komputer sebagai media pembelajarannya. Komputer digunakan sebagai pengganti pembelajaran tradisional dengan menyediakan perangkat lunak sebagai media belajar mandiri. Sedangkan e-learning berbasis jaringan internet merupakan pengembangan dari $e$ learning berbasis komputer. Pada e-learning berbasis jaringan internet digunakan jaringan internet dan fitur-fitur yang lain untuk membantu proses belajar mengajar. Jaringan internet telah membuka peluang untuk model pembelajaran yang beragam dalam pembelajaran di sekolah, di kampus, kegiatan pelatihan dan penelitian (Pande, Wadhai and Thakare, 2016). Keberadaan perangkat elektronik sebagai alat pengembang media sangat terbantu dengan adanya koneksi internet (Rulviana and Artikel, 2018). 
Dalam proses belajar mengajar, $e$ learning memerlukan media yang lebih spesifik untuk menunjang kegiatan tersebut. Edmodo merupakan salah satu alternatif media penunjang e-learning. Tampilan edmodo yang mirip dengan media sosial facebook memungkinkan penggunaan aplikasi ini dengan mudah. Karena edmodo termasuk media sosial, maka pengguna pun dapat mengakses aplikasi edmodo dengan gratis melalui sambungan internet. Edmodo adalah sebuah platform pembelajaran gratis dan aman yang dirancang oleh Nicolas Borg and Jeff O'Hara pada tahun 2008 untuk guru, siswa, orang tua, sekolah, dan pemerintahan dan dapat diakses melalui www.edmodo.com (Chada Kongchan: 2013). Adanya edmodo memungkinkan mahasiswa dan dosen berinteraksi online di luar jam kuliah reguler di kelas.

Kurikulum KKNI yang telah digunakan di Program Studi (Prodi) Pendidikan Fisika Universitas Pattimura menyatakan bahwa pembelajaran tatap muka di kelas dilaksanakan minimal 14 kali pertemuan. Berdasarkan observasi di Prodi Pendidikan Fisika terdapat berbagai kendala dijumpai sehingga kadang kala batas minimal pertemuan tersebut sulit tercapai. Seperti yang terjadi beberapa bulan yang lalu, di mana rentetan gempa bumi mengguncang Kota Ambon dan sekitarnya. Proses pembelajaran terpaksa terganggu dikarenakan beberapa bangunan rusak serta rentetan gempa susulan yang bertubi-tubi datang mengguncang. Untuk menjembatani terlaksananya tuntutan kurikulum maka dipilihkan model pembelajaran e-learning berbasis edmodo pada mata kuliah Sejarah Fisika. Menurut (Helaludin, 2019) seiring program Gerakan Literasi Sekolah yang di dalamnya berkembang menjadi literasi tekonologi literasi harus diimplementasikan kedalam jenjang pendidikan sedini mungkin. Hal ini dilakukan dalam upaya untuk melakukan pembaharuan dan inovasi pendidikan dalam menyongsong abad ke21. Aplikasi program literasi TIK ini dapat dilakukan mulai dari sekolah dasar, menengah, hingga level pendidikan tinggi. Tujuan dari penelitan ini adalah mengetahui kelayakan penerapan pembelajaran $e$ learning berbasis edmodo, mengetahui kelayakan perangkat pembelajaran yang diterapkan pada e-learning berbasis edmodo, mengetahui respon mahasiswa terhadap penerapan pembelajaran $e$ learning berbasis edmodo serta mengetahui hasil belajar mahasiswa pada mata kuliah Sejarah Fisika di Program Studi Pendidikan Fisika Universitas Pattimura setelah menerapkan pembelajaran e-learning berbasis edmodo.

\section{METODE}

Desain penelitian yang digunakan adalah "One Group Pre test- Post test Design", yaitu desain penelitian yang terdapat pre test sebelum diberi perlakuan dan post test setelah diberi perlakuan. 
Dengan demikian dapat diketahui lebih akurat, karena dapat membandingkan dengan diadakan sebelum diberi perlakuan (Sugiyono, 2012). Penelitian ini dilakukan di kelas mata kuliah Sejarah Fisika Program Studi Pendidikan Fisika Universitas Pattimura 2019.

Dalam penelitian ini digunakan tiga instrumen pengumpulan data yaitu: angket, tes, dan lembar observasi. Angket digunakan untuk mengetahui kelayakan perangkat pembelajaran yang diterapkan pada pembelajaran e-learning berbasis edmodo, kelayakan media edmodo dalam pembelajaran e-learning serta untuk mengetahui respon mahasiswa terhadap pembelajaran e-learning berbasis edmodo. Tes digunakan untuk mengukur hasil belajar mahasiswa sebelum dan setelah menggunakan media edmodo.

\section{Analisis Data}

Data kuantitatif diperoleh dari nilai pre test dan post test siswa. Dari hasil tersebut kemudian dianalisis untuk mengetahui peningkatan hasil belajar mahasiswa. Uji Gain digunakan untuk mengetahui peningkatan hasil belajar kognitif sebelum dan sesudah pembelajaran dilakukan dihitung dengan gain score ternormalisasi.

$$
<g>=\frac{\%<G>}{\%<G>_{\max }}=\frac{\%<S_{f}>-\%<S_{i}>}{\%<S_{m}>-\%<S_{i}>}
$$

Keterangan:

$\langle$ g $\rangle \quad=$ skor gain yang ternormalisasi

$\mathrm{S}_{\mathrm{f}} \quad=$ skor rerata post-test

$\mathrm{S}_{\mathrm{i}} \quad=$ skor rerata pre-test

$\mathrm{S}_{\mathrm{m}} \quad=$ skor maksimum

Gain score ternormalisasi $\langle\mathrm{g}>$ merupakan metode yang cocok untuk menganalisis hasil pre-test dan post-test. Tingkat perolehan gain score ternormalisasi dikategorikan ke dalam tiga kategori (Hake, 1998) yaitu:

Gain tinggi $\quad:(<\mathrm{g}>)>0.7$

Gain sedang $\quad: 0.7 \geq(\langle\mathrm{g}\rangle) \geq 0.3$

Gain rendah $\quad:(<\mathrm{g}>)<0.3$

Untuk mengetahui kelayakan dan respon digunakan analisis data yang sama yaitu dengan menghitung:

(Prosentase) $\%=\frac{\sum \text { Skor validator }}{\sum \text { Skor Maksimum }} \times 100 \%$

Hasil dari analisis dikatakan layak apabila rata-rata penilaian sebesar $\geq 61 \%$ dengan kriteria sebagai berikut:

Tabel 1. Skor Penilaian dan Kriteria Kelayakan

\begin{tabular}{lll}
\hline Penilaian Kuantitatif & Bobot & Penilaian Kualitatif \\
\hline $\mathbf{8 1 - 1 0 0}$ & 5 & Sangat Layak \\
$\mathbf{6 1 - 8 0}$ & 4 & Layak \\
$\mathbf{4 1 - 6 0}$ & 3 & Cukup Layak \\
$\mathbf{2 1 - 4 0}$ & 2 & Kurang Layak \\
$\mathbf{0 - 2 0}$ & 1 & Tidak Layak \\
\hline
\end{tabular}

(Sumber: Riduwan 2013: 13-15) 


\section{HASIL DAN PEMBAHASAN}

Kelayakan perangkat pembelajaran diperoleh dari validasi para ahli. Ahli yang terlibat di penelitian ini adalah dosen media pembelajaran dan dosen ketua tim teaching mata kuliah Sejarah Fisika. Media pembelajaran yang divalidasi adalah tampilan media e-learning edmodo sedangkan perangkat pembelajaran yang divalidasi berupa: Rencana Pembelajaran Semester (RPS) yang di dalamnya terdapat silabus, materi pembelajaran dan perangkat evaluasi. Hasil validasi para ahli diperoleh seperti diagram berikut:

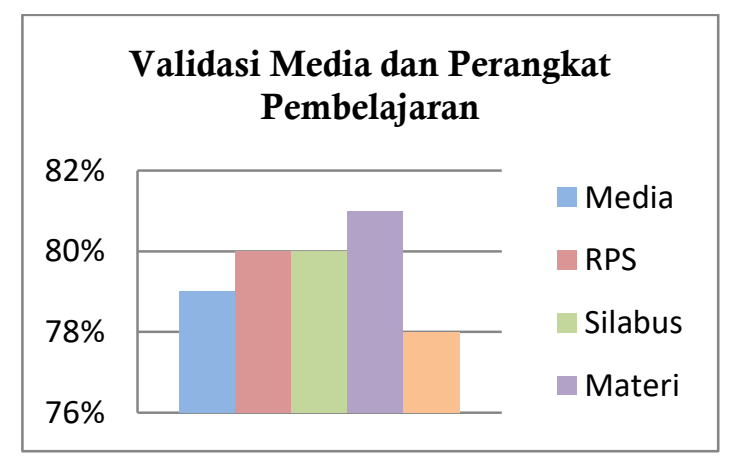

Gambar 1. Validasi Media dan Perangkat

$$
\text { Pembelajaran }
$$

Hasil belajar mahasiswa diperoleh dari pre test dan post test seperti tabel berikut:

Tabel 2. Nilai Rata-rata Pre Test dan Post Test

\begin{tabular}{cc}
\hline Jenis Test & Nilai Rata-rata \\
\hline Pre Test & 55 \\
Post Test & 80 \\
Nilai Tertinggi & 95 \\
\hline
\end{tabular}

Berdasarkan hasil belajar seperti pada Tabel 2, maka diperoleh nilai uji gain sebesar 0.65. Respon mahasiswa terhadap pembelajaran diperoleh dari angket yang diberikan pada akhir pertemuan. Angket berisi beberapa pertanyaan mengenai akses edmodo, tampilan media, dan motivasi mahasiswa terhadap penggunaan media dalam pembelajaran. Respon mahasiswa terhadap pembelajaran e-learning ditunjukkan pada diagram berikut:

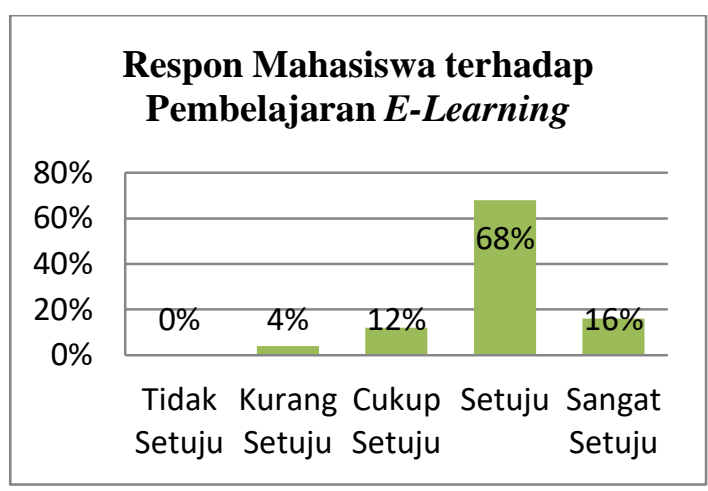

Gambar 2. Respon Mahasiswa terhadap Pembelajaran E-Learning

Berdasarkan Gambar 2. diperoleh sebanyak $0 \%$ mahasiswa tidak setuju penggunaan media edomodo, sebanyak $4 \%$ mahasiswa kurang setuju penggunaan media edomodo, sebanyak $12 \%$ mahasiswa cukup setuju penggunaan media edmodo, sebanyak $68 \%$ mahasiswa setuju penggunaan edmodo dan $16 \%$ menyatakan sangat setuju penggunaan edmodo dalam pembelajaran.

Pembelajaran e-learning berbasis edmodo dimulai dengan sosialisasi penggunaan edmodo untuk pembelajaran mata kuliah Sejarah Fisika. Langkah berikutnya adalah peneliti membuat akun 
edmodo mata kuliah tersebut. Setelah akun kelas pada edmodo selesai dibuat maka akan diperoleh kode kelas. Kode kelas tersebut diinfokan kepada mahasiswa agar mahasiswa dapat bergabung atau mendaftar di kelas edmodo Sejarah Fisika. Apabila peneliti dan mahasiswa sudah bergabung di kelas yang sama maka pembelajaran menggunakan edmodo dapat dilaksanakan. Peneliti membagikan materi kuliah melalui media edomodo sehingga mahasiswa dapat mengaksesnya. Peneliti juga akan memberikan tugas-tugas kepada mahasiswa dengan batas waktu pengumpulan yang sudah disepakati bersama. Interaksi mahasiswa dengan peneliti dilakukan melalu fitur-fitur yang tersedia di edomodo dan interaksi secara langsung face to face di kampus. Pembelajaran yang menggabungkan pembelajaran on line dengan pembelajaran face to face dinamakan blended learning (Thinh, 2016)

Berdasarkan analisis data diperoleh hasil validasi media pembelajaran edmodo sebesar 79\%. Validasi perangkat pembelajaran yang meliputi RPS, silabus, materi pembelajaran dan soal evaluasi diperoleh rata-rata sebesar $80 \%$. Menurut Riduwan (2013: 13-15) maka hasil validasi media pembelajaran edmodo dan validasi perangkat pembelajaran masuk dalam kriteria layak digunakan. Manfaat media pembelajaran menurut Kemp dan Dayton dalam Daryanto (2010:6) yaitu:

Penyampain pesan pembelajaran dapat lebih terstandar. (2) Pembelajaran menjadi lebih menarik. (3) Pembelajaran menjadi lebih interaktif dengan menerapkan teori belajar. (4) Waktu pelaksanaan pembelajaran dapat diperpendek. (5) Kualitas pembelajaran dapat ditingkatkan. (6) Proses pembelajaran dapat berlangsung kapan pun dan di mana pun. (7) Sikap positif siswa terhadap materi pembelajaran serta proses pembelajaran dapat meningkat. (8) Peran pendidik mengalami perubahan ke arah positif.

Uji Gain yang dilakukan terhadap hasil belajar mahasiswa diperoleh nilai $(<\mathrm{g}\rangle)$ sebesar 0.65. Nilai gain tersebut masuk dalam ketegori sedang. Artinya terjadi peningkatan hasil belajar yang kategori sedang setelah mahasiswa menggunakan edmodo sebagai media pembelajaran. Peningkatan hasil belajar mahasiswa sejalan dengan pendapat (Jethro, Grace and Thomas, 2012) yang menyebutkan bahwa keuntungan pembelajaran e-learning adalah (1) $E$ learning meningkatkan pengalaman belajar, dan memperluas jangkauan setiap dosen dan tutor. (2) E-learning menyediakan cara-cara baru dan kreatif untuk memotivasi dan melibatkan seluruh potensi siswa. (3) $E$ learning membantu siswa mengembangkan literasi data dan teknologi. (4) E-learning memberikan altertatif dalam pemilihan sumber belajar. (5) E-learning memciptakan komunitas on-line yang dapat menyatukan siswa, guru, pakar, dan kelompok belajar lainnya. (6) E-learning membantu siswa 
yang cacat fisik untuk tetap dapat memenuhi kebutuhan belajarnya.

Respon mahasiswa terhadap pembelajaran e-learning menguraikan tentang akses edmodo, tampilan media, dan motivasi mahasiswa terhadap penggunaan media dalam pembelajaran. Prosentase terbesar respon mahasiswa terhadap penggunaan pembelajaran e-learning yaitu sebanyak $68 \%$ yang menyatakan mahasiswa setuju menggunakan media e-learning dalam pembelajaran hal ini sejalan dengan penelitian (Hikmawan and Sarino, 2018) yang menerangkan bahwa pemanfaatan media pembelajaran memiliki pengaruh positif yang cukup kuat dan signifikan terhadap motivasi belajar siswa. Hal ini menunjukan bahwa motivasi belajar siswa dapat dipengaruhi oleh media pembelajaran berbasis edmodo. Prosentase terkecil respon mahasiswa terhadap penggunaan pembelajaran e-learning adalah 4\% yang menyatakan mahasiswa kurang setuju penggunaan pembelajaran e-learning. Menurut pendapat (Monika, 2013), kelemahan pembejaran e-learning adalah membuat mahasiswa tidak nyaman dan berpotensi frustasi atau kebingungan. Hal ini terjadi karena mahasiswa di program studi Pendidikan Fisika belum begitu familiar terhadap model pembelajaran e-learning. Media edomodo masih dirasa asing oleh sebagian mahasiswa. Tidak adanya pilihan bahasa Indonesia dalam aplikasi edmodo menambah kesulitan mahasiswa dalam menggunakan media tersebut. Sinyal internet yang kurang lancar di wilayah Maluku juga merupakan hambatan penggunaan pembelajaran e-learning .

\section{SIMPULAN DAN SARAN}

Berdasarkan hasil penelitian diperoleh kesimpulan: (1)Pembelajaran $e$ learning berbasis edmodo layak digunakan dalam pembelajaran. (2) Perangkat pembelajaran layak diterapkan dalam pembelajaran e-learning berbasis edmodo. (3) Mahasiswa merespon baik penerapan pembelajaran e-learning berbasis edmodo. (4) Terjadi peningkatan kategori sedang penerapan pembelajaran e-learning berbasis edmodo.

Untuk penelitian selanjutnya yang berhubungan dengan e-learning berbasis edmodo sebaiknya dilakukan sosialisasi dan pendampingan terhadap mahasiswa tentang cara mengakses edmodo. Selain itu jaringan internet yang kuat juga sangat dibutuhkan agar mahasiswa tidak kesulitan dalam proses pembelajaran e-learning.

\section{DAFTAR REFERENSI}

Algahtani, A.F. (2011). Evaluating the Effectiveness of the E-learning Experience in Some

Universities in Saudi Arabia from Male Students' Perceptions, Durham theses, Durham University

Arkoful, V. (2014). The role of e-learning, the advantages and disadvantages of its adoption in Higher Education. International of Education and Research, 2(12):397-410. 
Bezhovski, Z. (2016). The Evolution of ELearning and New Trends. Journal of Information and Knowledge, 6(3): 50-57.

Daryanto. (2010). Media Pembelajaran: Peranannya Sangat Penting Dalam Mencapai Tujuan Pembelajaran. Yogyakarta: Gava Media.

El-seoud, M. S. A. et al. (2009) .E-Learning and Students 'Motivation: A Research Study on the Effect of E-Learning on Higher Education. Cairo Paper, 9(4): 20-26.

Epignosis. (2014). E-Learning Concepts, Trends, Applications. San Francisco: LLC.

Hake, R. R. (1998). Interactive-Engagment vs Traditional Methods: A Six ThousandStudent Survey of Mechanics. Test Data for Introductory Physics Course. Am. J. Physics. 66, 64-74.

Hamalik,Oemar. (2011). Kurikulum Pembelajaran. Jakarta: Bumi Aksara.

Helaludin. (2019). Peningkatan Kemampuan Literasi Teknologi dalam Upaya Mengembangkan Inovasi Pendidikan di Perguruan Tinggi. Jurnal Pendais, 1(1):44-55.

Hikmawan, T. and Sarino, A. (2018) . Pemanfaatan Media Pembelajaran Berbasis Edmodo Kejuruan ( The Impact of Electronic Media Base Edmodo on Student , Motivation Learning at Vocational High School ). Jurnal Pendidikan Manajeman Perkantoran, 1(2):78-85.

Jethro, O. O., Grace, A. M. and Thomas, A. K. (2012). E-Learning and Its Effects on Teaching and Learning in a Global Age. International Journal of Academic Research in Bisnis and Social Science, 2(1):203-210.
Lin, H., Chen, W. and Nien, S. (2014). The Study of Achievement and Motivation by e-Learning - A Case Study. International Journal of Information and Education Technology, 4(5):421-425

Kongchan, Chada. (2013). "How Edmodo and Google Docs can change traditional classrooms" disajikan dalam The European Conference on Language Learning 2013, Brighton, United Kingdom, paper\#0442.

Mateo, Rey, P. d., \& Hernández. (2010) . Student motivation and cross-curricular development through e-learning applied to cooperation. The Future of Global Learning Engineering Education (EDUCON).

Monika, Č. (2013). Analysis of Perceptions of Conventional and E-Learning Education in Corporate Training. Journal of Competitiveness, 5(4):73-97.

Pande, D., Wadhai, V. M. and Thakare, V. M. (2016) . E-Learning System and Higher Education. Journal of Computer Science and Mobile Computing, 5(2): 274-280.

Riduwan. (2013). Skala Pengukuran Variabelvariabel Penelitian. Bandung: Alfabeta.

Rulviana, V. (2018). Implementasi Media Edmodo Dalam Mata Kuliah Pengembangan Kurikulum Sekolah Dasar. Jurnal Refleksi Edukatika, 8(2):205-208

Rusman. (2014). Model-model Pembelajaran. Jakarta : Raja Grafindo Persada.

Sugiyono. (2012). Metode Penelitian Kuntitatif Kualitatif dan $R \& D$. Bandung: Alfabeta.

Thinh, Duong Van. (2016). The Role of Elearning. Budapest: Management, Enterprise and Benchmarking in the 21st Century. 